\title{
Potential mechanism of action of J5 vaccine in protection against severe bovine coliform mastitis
}

\author{
Hilde Dosogne, Frédéric Vangroenweghe, Christian Burvenich*
}

Ghent University, Faculty of Veterinary Medicine, Department of Physiology, Biochemistry and Biometrics, Salisburylaan 133, 9820 Merelbeke, Belgium

(Received 15 May 2001; accepted 14 September 2001)

\begin{abstract}
Coliform mastitis is one of the most difficult diseases to treat in the modern dairy industry. Curative therapy with antibiotics remains only moderately effective and depends on the stage at which the disease is treated. The most successful strategies for combating coliform mastitis appear to be prevention by hygienic management or prophylactic immunization. The severity of clinical symptoms of coliform mastitis has been shown to be reduced by immunization with the Escherichia coli J5 vaccine. However, although the J5 vaccine has been licensed in the United States for about 10 years, the immunological basis of its mechanism of action is still unknown. Until now, protection by J5 vaccination has often been explained by a straightforward mechanism of enhanced antibody production resulting in increased opsonization of coliform bacteria and lipopolysaccharides (LPS). The possibility that $\mathrm{J} 5$ vaccination could decrease risk factors for coliform mastitis such as impaired blood polymorphonuclear neutrophil leukocyte (PMN) diapedesis has never been investigated. This review provides arguments to support the hypothesis that J5 vaccination may reduce the severity of coliform mastitis by inducing a condition of mammary gland hyper-responsiveness, characterized by a Thelper 1 (Th1) response and mediated by memory cells inside the mammary gland, finally resulting in enhanced PMN diapedesis upon an intramammary infection.
\end{abstract}

dairy cow / coliform mastitis / $\mathrm{J} 5$ vaccine / $\mathrm{T}$ cell / immune response

Résumé - Mécanismes d'action possibles du vaccin J5 dans la protection contre la mammite coliforme sévère de la vache laitière. La mammite coliforme est une des maladies les plus difficiles à traiter dans l'industrie laitière moderne. La thérapie curative avec des antibiotiques reste peu efficace, dépendant du stade de la maladie. Les stratégies les plus efficaces pour combattre la mammite semblent être la prévention par des mesures d'hygiène ou la prophylaxie vaccinale. La sévérité des symptômes cliniques de la mammite coliforme peut être réduite par immunisation avec le vaccin Escherichia coli J5. Cependant, alors que le vaccin J5 a été mis sur le marché aux États-Unis depuis

\footnotetext{
* Correspondence and reprints

Tel.: (32) 9 2647321; fax: (32) 9 2647499; e-mail: christian.burvenich@rug.ac.be
} 
environ 10 ans, les bases immunologiques de son mécanisme d'action ne sont pas connues. Jusqu'à présent, la protection par le vaccin $\mathrm{J} 5$ a souvent été attribuée à un simple mécanisme de stimulation de la production d'anticorps résultant en une augmentation de l'opsonization des bactéries coliformes et des lipopolysaccharides (LPS). La possibilité que la vaccination avec J5 pourrait diminuer les facteurs de risque de la mammite coliforme, tels qu'une diapédèse insuffisante des leucocytes neutrophiles polymorphonucléaires (PMN) sanguins, n'a jamais été étudiée. Cet article de synthèse cite des arguments supportant l'hypothèse que la vaccination avec J5 pourrait réduire la sévérité de la mammite coliforme en induisant une hyper-sensibilité de la glande mammaire. Celle-ci serait caractérisée par une réponse immunitaire de type "T helper 1" par l'entremise de cellules mémoire de la glande mammaire, résultant finalement dans une augmentation de la diapédèse de PMN suivant une infection intramammaire.

vache laitière / mammite coliforme / vaccin $\mathrm{J5}$ / cellule T / réponse immunitaire

\section{Table of contents}

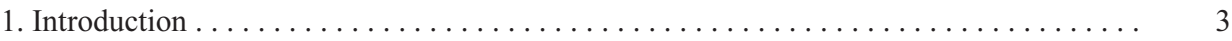

2. Potential mechanisms of action of the $\mathrm{J} 5$ vaccine $\ldots \ldots \ldots \ldots \ldots \ldots \ldots \ldots \ldots \ldots \ldots \ldots \ldots \ldots$

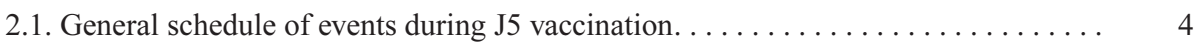

2.2. Hypothesis 1 : J5 vaccination could polarize the inflammatory response during

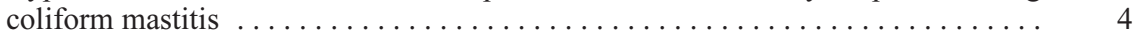

2.2.1. General characteristics of $\mathrm{T}$ helper type 1 and 2 responses ......... 4

2.2.2. Thelper type 1 immune response and delayed type hypersensitivity .... 5

2.2.3. Cell- or antibody-mediated types of hypersensitivity reactions? ....... 6

2.2.4. Underlying mechanism of failure to mount a Th1 response ......... 6

2.2.4.1. Lymphocyte phenotypes during the early postpartum period .... 6

2.2.4.2. Role of pregnancy and ageing in the polarization of the immune
response $\ldots \ldots \ldots \ldots \ldots \ldots \ldots \ldots \ldots \ldots \ldots \ldots \ldots \ldots \ldots$

2.2.5. Role of memory cells in the mammary gland . . . . . . . . . . . 7

2.2.5.1. Homing of memory $\mathrm{T}$ cells towards the mammary gland . . . . . . 7

2.2.5.2. Milk lymphocyte phenotypes during mastitis . . . . . . . . 7

2.2.6. Antigen-presenting cell requirements for Th1 differentiation ........ 8

2.3. Hypothesis $2: \mathrm{J} 5$ vaccination protects against severe coliform mastitis through
increased serum and milk antibody titers $\ldots \ldots \ldots \ldots \ldots \ldots \ldots \ldots \ldots \ldots \ldots$

2.3.1. Effect of $\mathrm{J} 5$ vaccination on serum and milk antibody titers . . . . . . . 8

2.3.2. Effect of lactation stage on antibody response . . . . . . . . . . 8

2.3.3. Effect of adjuvant and administration route on antibody response ...... 9

2.4. Influence of prior exposure to coliform pathogens and the effect on J5 vaccination . . 9

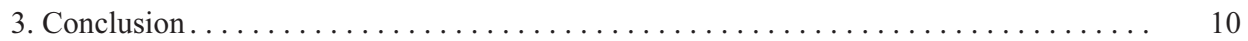




\section{INTRODUCTION}

The incidence of severe bovine mastitis caused by environmental bacteria such as Escherichia coli is quite high during the early postpartum period. A great individual variability between cows in biological responses to intramammary infections is observed during this period. In fact, all degrees of severity from peracute to subclinical are possible [54]. The susceptibility of individual cows to severe coliform mastitis appears to be associated with the degree of neutropenia or impairment of blood polymorphonuclear neutrophil leukocyte (PMN) function. The most important risk factors for severe $E$. coli mastitis are slow migration of blood PMN into the mammary gland $[14,23,55]$ and their impaired oxidative burst activity $[1,6,13]$. Lymphocyte function such as proliferation and antibody response has also been found to be impaired during early lactation [30], but a relation with the severity of coliform mastitis has not been clearly established.

The Escherichia coli J5 vaccine has been successfully used in the protection against severe coliform mastitis [10, 21]. Escherichia coli $\mathrm{J} 5$ is a rough (Rc) mutant E. coli strain. Upon J5 vaccination, antibodies are therefore generated against the core antigen, which consists of lipid A and some common core polysaccharides (2-keto-3-deoxyoctonate, heptose and glucose residues) (Fig. 1) [4, 53]. The presence of core antigen compounds only, which - in contrast with $\mathrm{O}$ antigens - are highly conserved among Gram negative bacteria, forms the basis of cross-protection against a wide range of Gram negative bacteria. At first sight, protection afforded by J5 vaccination appears to be related to increased specific antibody production against LPS core antigens and enhanced opsonization of bacteria. However, although serum and milk antibody titers are increased as a result

smooth Gram negative bacteria

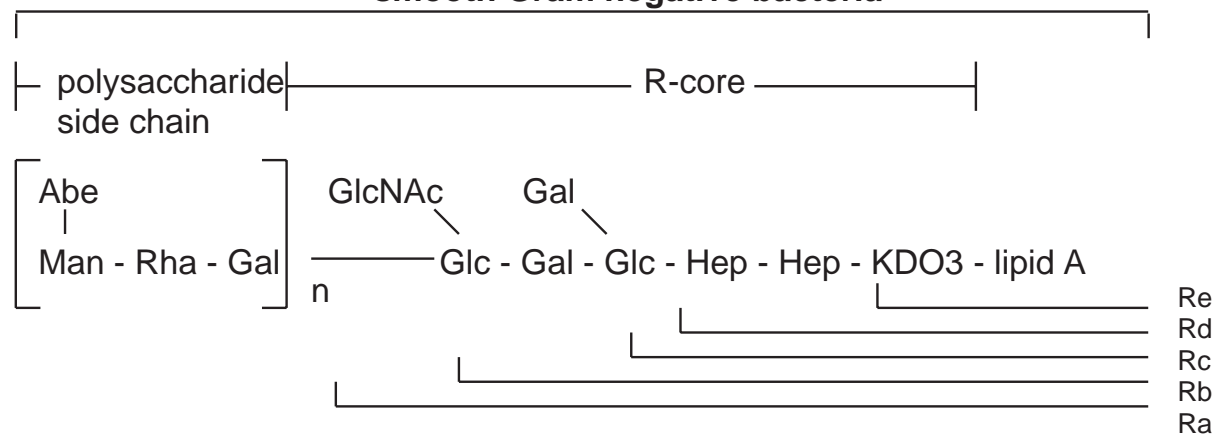

E. coli J5 "core antigen"

Figure 1. Lipopolysaccharide (LPS) structure of smooth and rough Gram negative bacteria. The LPS structure of smooth bacteria consists of a polysaccharide side chain (O antigen), R-core polysaccharides and lipid A. The LPS structure of Escherichia coli J5 (a rough Rc mutant) lacks the $\mathrm{O}$ antigen and consists only of lipid A and some common core polysaccharides (2-keto-3-deoxyoctonate, 2 heptose and 1 glucose residues). Together, this LPS structure is called the "core antigen". Abe, abequose; Man, mannose; Rha, Rhamnose; Gal, galactose; GlcNAc, N-acetylglucosamine; Glc, glucose; Hep, Heptose; KDO, 2-keto-3-deoxyoctonate (after [53]). 
of vaccination $[18,19]$, a proportionally decreased incidence and severity of $E$. coli mastitis has not always been readily apparent $[15,21]$. There is practically no information available about the effects of $\mathrm{J} 5$ vaccination on risk factors for severe coliform mastitis such as decreased PMN number and function. From the important role of PMN in the pathogenesis of coliform mastitis as described above, it can be proposed that the mechanism of action of J5 vaccination should be based on the re-establishment or compensation for reduced PMN functions in order to reduce severity during coliform mastitis.

\section{POTENTIAL MECHANISMS OF ACTION OF THE J5 VACCINE}

Mastitis research has been concentrated on the role of PMN as a defense mechanism by itself; less attention has been paid on the characterization of lymphocyte-mediated mechanisms activating these cells. Several recent studies $[29,44]$ suggest that lymphocytes could also play an important role, but their precise function in the pathogenesis of coliform mastitis remains unclear. Two major pathways for a role of lymphocytes in the mechanism of action of $\mathrm{J} 5$ vaccination are explored: (1) modulation of the T cell mediated immune response; and (2) opsonizing or neutralizing effects of enhanced serum and/or milk antibody titers.

\subsection{General schedule of events during J5 vaccination}

The events that will theoretically occur during J5 vaccination can be derived from human and mouse models (Fig. 2) (reviewed by Guidry and O'Brien [12]). Upon subcutaneous vaccination, the vaccine first binds to resident antigen-presenting cells (APC) which can be macrophages, activated B cells or dendritic cells. After antigen processing, the resulting products are expressed on the membrane surface in conjunction with major histocompatibility class II (MHCII) molecules. Antigen-presenting cells migrate to lymphoid tissues, where they bind to $\mathrm{CD}^{+} \mathrm{T}$ cells ( $\mathrm{T}$ helper cells, Th). Both $\mathrm{CD}^{+}$and $\mathrm{CD}^{+}$(cytotoxic, Tc or suppressor T cells, Ts) belong to the class of $\alpha \beta T$ cells. These cells can develop memory, resulting in a faster and more pronounced response after a 2 nd or 3 rd contact. Milk lymphocytes of healthy cows indeed display the phenotype of memory/activated cells [39, 48].

\subsection{Hypothesis 1: J5 vaccination could polarize the inflammatory response during coliform mastitis}

\subsubsection{General characteristics of Thelper type 1 and 2 responses}

Upon binding of APC with $\mathrm{CD}^{+} \mathrm{T}$ cells, the immune response can be classified as a Th1 or Th2 response. Th1 responses are characterized by activation of macrophages and PMN adhesion, diapedesis and opsonization. Typical Th1 cytokines are interleukin-2 (IL-2, growth and proliferation of Th1 lymphocytes), IL-8 (stimulation of PMN chemotaxis and induction of endothelial binding sites on PMN), IL-12 (induction of interferon (IFN) production), IFN- $\beta$ (stimulation of leukocyte adhesion) and IFN- $\gamma$ (stimulation of cytotoxicity and inhibition of antibody production). A typical Th2 response consists of B cell activation to proliferate and differentiate into antibody-producing plasma cells. Th2 cytokines are IL-4 (stimulation of maturation and Ig class switching), IL-5 (stimulation of B cell proliferation and differentiation) and IL-10 (inhibition of cell- mediated immunity) (reviewed by Guidry and O'Brien [12]). From these data it can be proposed that a Th1 response would be beneficial in the outcome of $E$. coli mastitis, because of its stimulatory effects on PMN diapedesis. 


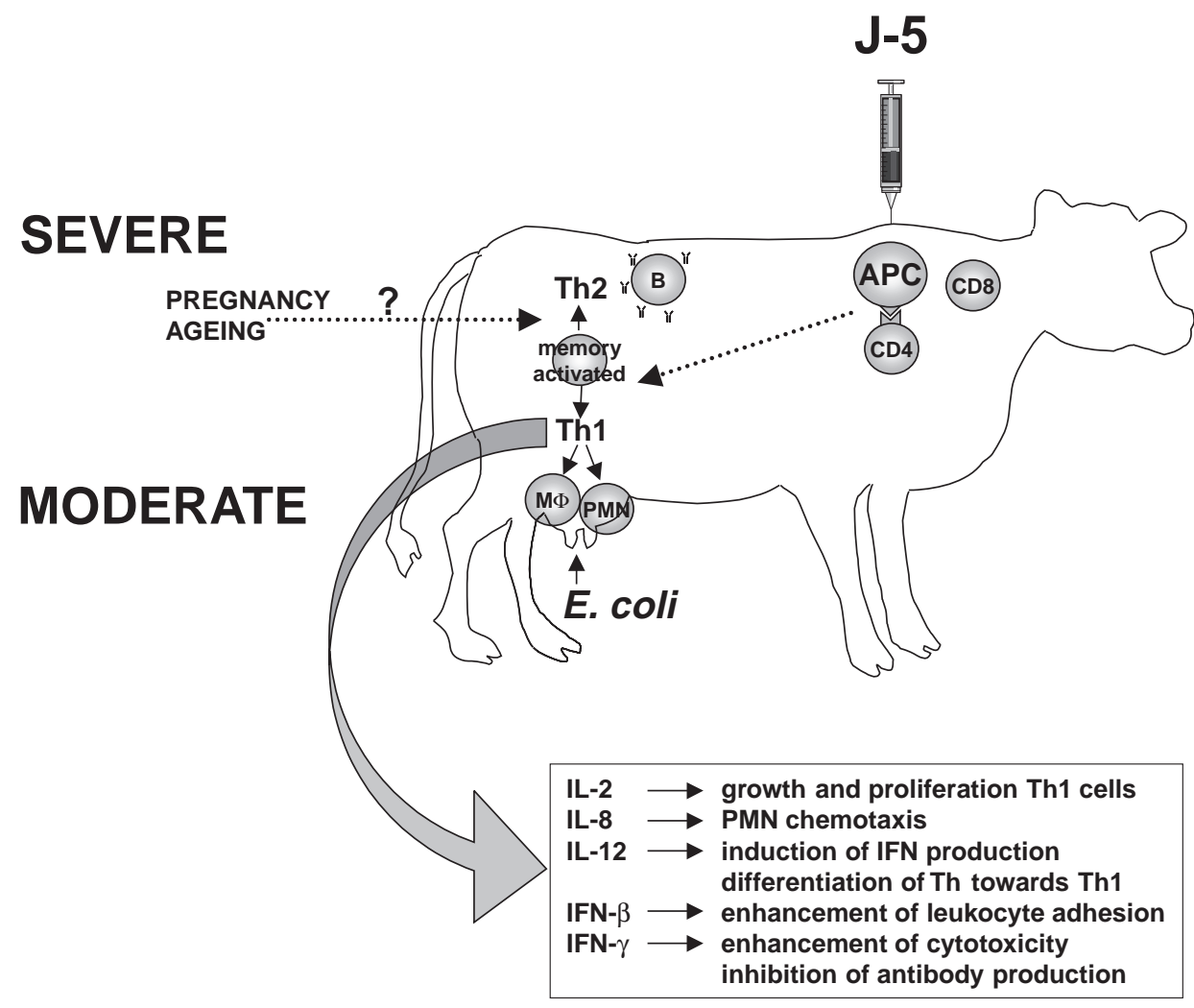

Figure 2. Potential mechanism of action of the $\mathrm{J} 5$ vaccine in reducing severity of coliform mastitis in dairy cows. Escherichia coli J5 first binds to antigen-presenting cells (APC) which can be macrophages, activated B cells or dendritic cells (DC). After antigen processing, the product is expressed on the membrane surface in conjunction with major histocompatibility class II (MHCII) molecules. APC migrate to lymphoid tissues, where they bind to $\mathrm{CD}^{+} \mathrm{T}$ cells ( $\mathrm{T}$ helper cells, $\mathrm{Th}$ ). Both $\mathrm{CD}^{+} \mathrm{T}$ cells and DC can develop memory, so that the response upon intramammary coliform infections in J5-vaccinated cows will be faster and more pronounced than in non-vaccinated cows. $\mathrm{CD}^{+} \mathrm{T}$ cells and DC can migrate towards the mammary gland. During coliform mastitis, APC binding with $\mathrm{CD} 4^{+} \mathrm{T}$ cells can result in a Th1 or Th2 response. Th1 responses are characterized by activation of macrophages and PMN adhesion, diapedesis and opsonization whereas a typical Th2 response consists of B cell proliferation and differentiation. From these data it is hypothesized that a Th1 response is preferentially mounted in $\mathrm{J} 5$-vaccinated cows, because this would benefit the outcome of $E$. coli mastitis. This could be mediated by memory $\mathrm{CD}^{+} \mathrm{T}$ cells and/or $\mathrm{DC} 1$ cells within the mammary gland. The inability to mount a Th1 response in severely diseased cows during coliform mastitis could be tentatively attributed to pregnancy and/or ageing.

\subsubsection{Thelper type 1 immune response and delayed type hypersensitivity}

A typical moderate response during coliform mastitis is consistent with the characteristics of a Th1 type response: enhanced
PMN migration, diapedesis and activation (Fig. 2). This hypothesis is supported by the positive effects of IFN- $\gamma$ treatment on the outcome of E. coli mastitis [47]. Delayed type hypersensitivity (DTH) reactions are also part of the Th1 response and may be 
induced by $\mathrm{J} 5$ vaccination. Preliminary evidence for the existence of DTH reactions in the bovine mammary gland comes from an experiment in which enhanced PMN diapedesis into the mammary gland was induced after intramammary ovalbumin (OA) injection in subcutaneously OA vaccinated cows [5]. These results suggested that an antigen-specific pathway could be elicited in the mammary gland upon subcutaneous immunization with that specific antigen. This could also be the case during J5 vaccination, because PMN infiltration into the mammary gland has been enhanced in vaccinated cows [19]. Similar findings have recently been obtained with Staphylococcus aureus $\alpha$-toxin immunized cows [39].

\subsubsection{Cell- or antibody-mediated types of hypersensitivity reactions?}

The etiology of hypersensitivity is complex: even in human medicine hypersensitivity reactions are difficult to classify as antibody- or cell-mediated. Because the effects seen in subcutaneously OA-vaccinated cows could not be mimicked by intramammary infusion of antigen-antibody complexes [5], it seems likely that possible hypersensitivity reactions during J5 vaccination are cell- and not antibody-mediated. This hypothesis is supported by the observation that treatment of mice [11] and neonatal calves [31] with J5 antiserum did not protect them against shock during intravenous LPS injection. These observations support the hypothesis of a cell-mediated pathway during J5 vaccination, rather than passive protection through increased serum or milk antibody titers.

\subsubsection{Underlying mechanism of failure to mount a Th1 response}

\subsubsection{Lymphocyte phenotypes during the early postpartum period}

Failure of the immune response in dairy cows during coliform mastitis could be associated with changes in the phenotype of blood mononuclear cells during the periparturient period. A dramatic decrease of some blood T cell subsets were observed shortly after parturition, whereas B cells were unchanged [24]. During early lactation, a decreased $\mathrm{CD}^{+}$to $\mathrm{CD} 8^{+}$milk lymphocyte ratio was found [33]. Kimura et al. [22] reported a significant decrease of blood $\mathrm{CD}^{+}, \mathrm{CD}^{+}$and $\gamma \delta \mathrm{T}$ cells at parturition. Decreased amounts of Th cells have indeed been used as indicators for an impaired immune function.

\subsubsection{Role of pregnancy and ageing in the polarization of the immune response}

Pregnancy has been proposed to cause the maternal immune system to preferentially mount a Th2 response [58] (Fig. 2). As a Th1 response may result in fetal absorption, the Th1 cytokines are generally harmful to the maintenance of pregnancy. Bovine blood $\mathrm{CD}^{+}$lymphocytes have indeed been shown to function primarily as Th2 effector cells during the postpartum period [44]. It appears that Th2 cytokines are predominantly produced by cells from the feto-placental unit in humans. Vaccination with paternal lymphocytes results in a shift towards a Th2 response and is associated with successful pregnancy in patients with recurrent spontaneous abortions [42]. In dairy cows, modulation of PMN function by placenta-derived glycoproteins has been found $[7,16]$, but their role in immune modulation during coliform mastitis is not completely understood. The phenomenon that pregnancy can modulate the immune response towards Th2 could therefore explain the decreased capacity to mount an adequate Th1 response during coliform mastitis in early postpartum dairy cows. Malfunction of the immune system in the elderly also appears to be associated with a Th1 to Th2 cytokine production shift [9]. Increased susceptibility to severe coliform mastitis has also been observed in older cows [55] (Fig. 2). Together, these findings 
suggest that impairment of the immune system in periparturient and in older cows could also be associated with a shift in cytokine synthesis during coliform mastitis.

\subsubsection{Role of memory cells in the mammary gland}

The inflammatory response upon intramammary challenge could be accelerated if memory cells were present inside the mammary gland. These memory or activated cells could be $\mathrm{T}$ lymphocytes or dendritic cells that have specifically migrated (homing) from local subcutaneous lymph nodes at the site of J5 vaccination towards the mammary gland (Fig. 2).

\subsubsection{Homing of memory T cells towards the mammary gland}

The homing phenomenon in general and to the mammary gland in particular is poorly characterized in dairy cows. A hypothetical pathway can be derived from human, rat or sheep models. Migration of memory $\mathrm{T}$ cells occurs preferably through non-lymphoid tissues whereas naïve T cells migrate to lymph nodes. The presence of lymphocytes in tissues is part of mucosal immunity. These tissues are called "mucosa associated lymphoid tissues (MALT)". MALT is structurally characterized by follicle-associated lymphoepithelium and the presence of secondary follicles [3]. It can also be immunohistochemically identified by the presence of migrating activated lymphocytes and IgA producing plasma cells [2]. Typical MALT are the gut, lungs, nose (rodents), mesenteric lymph nodes, skin and subcutaneous lymph nodes (sheep) and the mammary gland (pigs). In cows, the presence of MALT has been described in the intestine [34] and in tonsils [36]. Histological evidence for MALT inside the bovine mammary gland tissue is not available, but plasma cells have been demonstrated in mammary gland mucosa, with increasing concentrations from milk-secreting parenchyma to the distal teat end mucosa [32]. The local production of $\operatorname{IgA}, \operatorname{IgM}$ and IgG2 in mammary tissue has also been demonstrated [35].

Homing of lymphocytes is controlled by the expression of homing receptors on lymphocytes and vascular addressins in the venules of the lamina propria of the gut and of the lactating mammary gland [59]. Tissue-specific $\mathrm{T}$ cell migration is predominantly a characteristic of $\alpha \beta \mathrm{T}$ cells $\left(\mathrm{CD}^{+}\right.$ and $\mathrm{CD} 8^{+}$cells), whereas $\gamma \delta$ T cells migrate randomly [57]. More recent studies in sheep have shown that tissue-specific migration is restricted to $\mathrm{CD}^{+}$memory cells [28]. The number of lymphocytes in the porcine mammary gland increases from day 80 of pregnancy until parturition, under the influence of increased prolactin receptor density [40]. This suggests that homing towards the mammary gland may also occur through hormonal alterations in dairy cows. Actual data on bovine lymphocyte homing are, however, scarce. Milk lymphocytes display the phenotype of memory cells $[39,48]$. The percentage of memory cells in milk was up-regulated following subcutaneous $S$. aureus $\alpha$-toxin immunization [39]. Although these authors used a different model than J5 vaccination, their findings support the general concept that memory $T$ cells can specifically migrate towards the mammary gland in immunized cows.

\subsubsection{Milk lymphocyte phenotypes during mastitis}

During $S$. aureus $\alpha$-toxin induced mastitis, $\mathrm{CD}^{+}$cells were recruited into milk earlier than $\mathrm{CD}^{+}$cells: $12 \mathrm{~h}$ and $96 \mathrm{~h}$ after challenge, respectively [39]. This suggests an important role of $\mathrm{CD}^{+}$cells as effector cells in intramammary defense of immunized cows. In field cases, the $\mathrm{CD}^{+}$to $\mathrm{CD}^{+}$ratio of milk cells was increased during staphylococcal mastitis whereas it remained constant during streptococcal mastitis [46]. From these data it is clear that 
changes in proliferation and trafficking of $\mathrm{CD}^{+}$and $\mathrm{CD}^{+}$are dependent on the antigenic stimulus and that lymphocytes probably play a crucial role in regulating the inflammatory response of the bovine mammary gland. The effect of $\mathrm{J} 5$ vaccination on the phenotype of milk lymphocytes in healthy cows and their response upon intramammary infections with coliform bacteria is presently unknown.

\subsubsection{Antigen-presenting cell requirements for Th1 differentiation}

The APC requirements for differentiation of naïve $\mathrm{CD} 4^{+}$cells into Th1 cells in J5-vaccinated cows are presently unknown. Both macrophages and dendritic cells but not B cells were found to play a role in the induction of Th1 development in mice [27]. Findings in humans also suggest that monocyte-derived dendritic cells (DC) play an important role in the generation of a polarized immune response. Committed DC are currently used for vaccination in cancer patients in order to induce a Th1-dominant immune response and stimulate a DTH reaction, which is required for the induction of tumor regression [38]. Optimal activation of T lymphocytes indeed depends on $\mathrm{T}$ cell receptor interaction with peptide/MHC complexes in conjunction with costimulatory signals, delivered by APC. Dendritic cells are widely distributed in tissues and play a major role in the induction of primary $\mathrm{T}$ cell dependent immune responses [37]. The Th1/Th2 commitment of $\mathrm{T}$ cells appears to occur within clusters of DC and T cells in T cell areas of lymphoid tissues where DC1 induce the differentiation of Th1 cells and DC2 induce Th2 cells. This commitment is controlled by typical Th1 and Th2 cytokines, respectively [43]. The role of DC in the pathogenesis of coliform mastitis and in the modulation of the immune response in J5-vaccinated cows currently remains unknown.

\subsection{Hypothesis 2: $\mathrm{J5}$ vaccination protects against severe coliform mastitis through increased serum and milk antibody titers}

\subsubsection{Effect of J5 vaccination on serum and milk antibody titers}

The classical hypothesis for a mechanism of action of $\mathrm{J} 5$ vaccination consists in the protection by enhanced opsonization of LPS and bacteria by increased serum and milk antibody titers. Immunization with the $\mathrm{J} 5$ vaccine indeed increases antibody titers to $E$. coli $\mathrm{J} 5$ core antigens in serum and mammary secretions [50]. In a field study, high serum IgG1 titers against $E$. coli O111: B4 (J5) were associated with a decreased incidence of clinical coliform mastitis [51]. In addition, serum from J5 vaccinated cows showed enhanced in vitro opsonic activity for E. coli [17]. Thus, it can be hypothesized that $\mathrm{J} 5$ vaccination may protect against severe coliform mastitis by stimulation of specific antibody production against the common core antigen of Gram-negative bacteria, resulting in enhanced opsonization of bacteria and LPS. However, although increased serum and milk specific antibody titers are generally observed following $\mathrm{J} 5$ vaccination, a relation with the incidence or severity of mastitis has not always been established $[15,50]$. Further evidence to reject the hypothesis that increased antibody titers provide protection in J5-vaccinated cows, comes from the conclusion of Hill [14] that opsonins are not a limiting factor in the pathogenesis of coliform mastitis. A fast PMN diapedesis and the availability of a high number of active PMN inside the infected mammary gland are much more critical for the outcome of severe coliform mastitis $[14,23$, $54,55]$.

\subsubsection{Effect of lactation stage on antibody response}

Variability in antibody response to J5 immunization could be the result of variable 
immunosuppression in early lactation dairy cows. For example, serum IgG2 titers recognizing $E$. coli $\mathrm{J} 5$ common core antigen following vaccination showed a coefficient of variation of $64 \%$ [15]. Serum antibody titers in J5 vaccinated cows are generally higher than in control cows, but significant effects of lactation stage on milk and serum IgG and IgM titers have been observed in both control and J5 vaccinated cows [18, 21, 45, 49]. Furthermore, periparturient cows can be phenotypically classified as low or high responders to immunization, based on the magnitude and kinetics of the antibody response to E. coli J5 or ovalbumin injection [29, 56]. Whereas about one third of the cows responded normally, two third showed a variable degree of hyporesponsiveness to peripartum immunization $[29,56]$. These findings suggest that the immune deficiency which makes cows susceptible to E. coli mastitis may therefore also impair antibody response to active immunization during early lactation.

\subsubsection{Effect of adjuvant and administration route on antibody response}

The antibody response to $\mathrm{J} 5$ immunization appears to be dependent on the adjuvant and the route of administration. In vaccinated neonatal calves, a significant increase in antibody titers was only observed with Freund incomplete adjuvant [52]. The route of immunization also appears to play a role in the antibody response. A vaccination schedule that included intramammary immunization between 2 subcutaneous immunizations resulted in higher serum antibody titers than the conventional vaccination schedule with 3 subcutaneous immunizations [20]. The enhancement of IgG and IgM titer responses in milk and serum by intramammary immunization has been explained by the possibility that cells stimulated locally in the mammary gland may travel to local lymphatic tissues, thereby increasing systemic antibody response [49].

\subsection{Influence of prior exposure to coliform pathogens and the effect on $\mathrm{J} 5$ vaccination}

It is unlikely that naturally occurring intramammary infections with coliform pathogens could confer immunological memory such as with subcutaneous $E$. coli $\mathrm{J} 5$ vaccination. Firstly, the variability in genotypes among wild-type coliform mastitis pathogens is very high $[26,41]$. This would highly limit the formation of cross-reactive antibodies or memory cells. Secondly, plasma antibody titers were not increased after intramammary $E$. coli infections in both control and J5-vaccinated cows [21]. This suggests that the intramammary route of immunization does not result in the formation of memory cells, in contrast with subcutaneous vaccination. Similar results are, however, obtained with $\mathrm{J} 5$ vaccination into the supramammary lymph node and subcutaneously in the neck [49]. This suggests an important role for interaction between antigen and immune cells within lymphoid tissues in the formation of immunological memory. During naturally occurring intramammary infections with coliforms, however, the antigen will probably never reach the supramammary lymph node because the attachment of coliform bacteria to mammary epithelium, which would be a first necessary step, has never been observed $[8,25]$. Thirdly, older cows which normally underwent more intramammary infections - are more susceptible to severe coliform mastitis [55]. Age or prior exposure to pathogens also did not influence antibody response to immunization with J5 or ovalbumin $[29,56]$. Together, these data suggest a quite limited role - if any - for prior natural exposure to coliform mastitis pathogens in protection against severity. 


\section{CONCLUSION}

The mechanism of protection against severe coliform mastitis through $\mathrm{J} 5$ vaccination is presently unknown. Data in the literature support the hypothesis that it may act by inducing a state of hyper-responsiveness within the mammary gland, mediated by local memory cells. These cells could contribute to the polarization of the immune response towards a Th1 response resulting in enhanced PMN infiltration upon intramammary challenge.

\section{ACKNOWLEDGEMENTS}

This study has been supported by the Belgian Ministry of Small Enterprises and Agriculture (grant S-6014), the Belgian "Fonds voor Wetenschappelijk Onderzoek" (FWO, grant 31504200) and the Belgian "Instituut tot aanmoediging van Innovatie door Wetenschap en Technologie" (post-doctoral research grant IWT/OZM/000445 to Hilde Dosogne).

\section{REFERENCES}

[1] Burvenich C., Dosogne H., Detilleux J., van Werven T., Is it possible to predict the severity of acute mastitis during early lactation through measurement of the activity of circulating polymorphonuclear cells ? Proceedings Journées Nationales GTV-INRA, 1999, pp. 43-52.

[2] Butcher E.C., Picker L.J., Lymphocyte homing and homeostasis, Science 272 (1996) 60-66.

[3] Croitoru K., Bienenstock J., Characteristics and functions of mucosa-associated lymphoid tissue, in: Ogra P.L., Lamm M.E., McGhee J.R., Mestecky J., Strober W., Bienenstock J. (Eds.), Handbook of Mucosal Immunology, Academic Press, San Diego, CA, 1994, pp. 414-449.

[4] Cullor J.S., J5 Escherichia coli: a core antigen vaccine for coliform mastitis, Coliform mastitis symposium proceedings, Washington State University, College of Veterinary Medicine, 1993, pp. 30-35.

[5] De Cueninck B.J., Immune-mediated inflammation in the lumen of the bovine mammary gland, Int. Arch. Allergy Appl. Immunol. 59 (1979) 394-402.

[6] Dosogne H., Burvenich C., van Werven T., Roets E., Noordhuizen-Stassen E.N., Goddeeris B., In- creased surface expression of CD11b receptors on polymorphonuclear leukocytes is not sufficient to sustain phagocytosis during Escherichia coli mastitis in early postpartum dairy cows, Vet. Immunol. Immunopathol. 60 (1997) 47-59.

[7] Dosogne H., Burvenich C., Freeman A.E., Kehrli M.E. Jr., Detilleux J.C., Sulon J., Beckers J.-F., Hoeben D., Pregnancy-associated glycoprotein and decreased polymorphonuclear leukocyte function in early post-partum dairy cows, Vet. Immunol. Immunopathol. 67 (1999) 47-54.

[8] Frost A.J., Hill A.W., Brooker B.E., The early pathogenesis of bovine mastitis due to Escherichia coli, Proc. R. Soc. Lond. B. Biol. Sci. 209 (1980) 431-439.

[9] Ginaldi L., De Martinis M., D’Ostilio A., Marini L., Loreto M.F., Quaglino D., The immune system in the elderly: III. Innate immunity, Immunol. Res. 20 (1999) 117-126.

[10] Gonzales R.N., Cullor J.S., Jasper D.E., Farver T.B., Brushnell R.B., Oliver M.N., Prevention of clinical coliform mastitis in dairy cows by a mutant Escherichia coli vaccine, Can. J. Vet. Res. 53 (1989) 301-305.

[11] Greisman S.E., Johnston C.A., Failure of antisera to J5 and R595 rough mutants to reduce endotoxemic lethality, J. Infect. Dis. 157 (1988) 54-64.

[12] Guidry A.J., O’Brien C.N., Current awareness of bovine mammary gland immunology, Flem. Vet. J. Suppl. 66 (1997) 341-358.

[13] Heyneman R., Burvenich C., Vercauteren R., Interaction between the respiratory burst activity of neutrophil leukocytes and experimentally induced Escherichia coli mastitis in cows, J. Dairy Sci. 73 (1990) 985-994.

[14] Hill A.W., Factors influencing the outcome of Escherichia coli mastitis in the dairy cow, Res. Vet. Sci. 31 (1981) 107.

[15] Hill A.W., Vaccination of cows with rough Escherichia coli mutants fails to protect against experimental intramammary bacterial challenge, Vet. Res. Commun. 15 (1991) 7.

[16] Hoeben D., Monfardini E., Opsomer G., Burvenich C., Dosogne H., De Kruif A., Beckers J.-F., Chemiluminescence of bovine polymorphonuclear leukocytes during the periparturient period and relation with metabolic markers and bovine pregnancy-associated glycoprotein, J. Dairy Res. 67 (2000) 249-259.

[17] Hogan J.S., Todhunter D.A., Tomita G.M., Smith K.L., Schoenberger P.S., Opsonic activity of bovine serum and mammary secretion after Escherichia coli J5 vaccination, J. Dairy Sci. 75 (1992) 72-77.

[18] Hogan J.S., Weiss W.P., Todhunter D.A., Smith K.L., Schoenberger P.S., Efficacy of an Escherichia coli J5 mastitis vaccine in an experimental challenge trial, J. Dairy Sci. 75 (1992) 415-422. 
[19] Hogan J.S., Weiss W.P., Smith K.L., Todhunter D.A., Schoenberger P.S., Effects of an Escherichia coli $\mathrm{J} 5$ vaccine on mild clinical coliform mastitis, J. Dairy Sci. 78 (1995) 285-290.

[20] Hogan J.S., Smith K.L., Schoenberger P., Roming S., Thompson L., Antibody titer responses to intramammary immunization with Escherichia coli J5 bacterin, J. Dairy Sci. 80 (1997) 2398-2402.

[21] Hogan J.S., Bogacz V.L., Aslam M., Smith K.L., Efficacy of an Escherichia coli J5 bacterin administered to primigravid heifers, J. Dairy Sci. 82 (1999) 939-943.

[22] Kimura K., Goff J.P., Kehrli M.E. Jr., Effects of the presence of the mammary gland on expression of neutrophil adhesion molecules and myeloperoxidase activity in periparturient dairy cows, J. Dairy Sci. 82 (1999) 2385-2392.

[23] Kremer W.D.J., Noordhuizen-Stassen E.N., Grommers F.J., Daemen A.J.J.M., Henricks P.A.J., Burvenich C., Brand A., Preinfection chemotactic response of blood polymorphonuclear leukocytes to predict severity of Escherichia coli bovine mastitis, J. Dairy Sci. 76 (1993) 1568-1574.

[24] Lacey-VanKampen C., Mallard B.A., Effects of peripartum stress and disease on bovine lymphocyte subsets, Vet. Immunol. Immunopathol. 59 (1998) 79-92.

[25] Lammers A., van Vorstenbosch C.J., Erkens J.H.F., Smith H.E., The major bovine pathogens have different cell tropisms in cultures of bovine mammary gland cells, Vet. Microbiol. 80 (2001) 255-265.

[26] Lipman L.J., de Nijs A., Lam T.J., Gaastra W., Identification of Escherichia coli strains from cows with clinical mastitis by serotyping and DNA polymorphism patterns with REP and ERIC primers, Vet. Microbiol. 43 (1995) 13-19.

[27] Macatonia S.E., Hsieh C.S., Murphy K.M., O'Garra A., Dendritic cells and macrophages are required for Th1 development of CD4+ T cells from alpha beta TCR transgenic mice: IL-12 substitution for macrophages to stimulate IFN-gamma production is IFN-gamma-dependent, Int. Immunol. 5 (1993) 1119-1128.

[28] Mackay C.R., Andrew D.P., Briskin M., Ringler D.J., Butcher E.C., Phenotype and migration properties of three major subsets of tissue homing $\mathrm{T}$ cells, Eur. J. Immunol. 26 (1996) 2433-2439.

[29] Mallard B.A., Wagter L.C., Ireland M.J., Dekkers J.C.M., Effects of growth hormone, insulin-like growth factor I and cortisol on periparturient antibody response profiles of dairy cattle, Vet. Immunol. Immunopathol. 60 (1997) 61-76.

[30] Mallard B.A., Dekkers J.C., Ireland M.J., Leslie K.E., Sharif S., Lacey Vankampen C., Wagter L., Wilkie B.N., Alteration in immune responsiveness during the peripartum period and its ramifi- cation on dairy cow and calf health, J. Dairy Sci. 81 (1998) 585-595.

[31] Morris D.D., Cullor J.S., Whitlock R.H., Wickstrom M., Corbeil L.B., Endotoxemia in neonatal calves given antiserum to a mutant Escherichia coli (J5), Am. J. Vet. Res. 47 (1986) 2554-2565.

[32] Nickerson S.C., Pankey J.W., Boddie N.T., Distribution, location, and ultrastructure of plasma cells in the uninfected, lactating bovine mammary gland, J. Dairy Res. 51 (1984) 209-217.

[33] Park Y.H., Fox L.K., Hamilton M.J., Davis W.C., Bovine mononuclear leukocyte subpopulations in peripheral blood and mammary gland secretions during lactation, J. Dairy Sci. 75 (1992) 998-1006.

[34] Parsons K.R., Howard C.J., Jones B.V., Sopp P., Investigation of bovine gut associated lymphoid tissue (GALT) using monoclonal antibodies against bovine lymphocytes, Vet. Pathol. 26 (1989) 396-408.

[35] Persson K., Carlsson A., Hambleton C., Guidry A.J., Immunoglobulins, lysozyme and lactoferrin in the teat and udder of the dry cow during endotoxin-induced inflammation, J. Vet. Med. B 39 (1992) 165-174.

[36] Rebelatto M.C., Mead C., HogenEsch H., Lymphocyte populations and adhesion molecule expression in bovine tonsils, Vet. Immunol. Immunopathol. 73 (2000) 15-29.

[37] Renjifo X., Howard C., Kerkhofs P., Denis M., Urbain J., Moser M., Pastoret P.P., Purification and characterization of bovine dendritic cells from peripheral blood, Vet. Immunol. Immunopathol. 60 (1997) 77-88.

[38] Rieser C., Ramoner R., Holtl L., Rogatsch H., Papesh C., Stenzl A., Bartsch G., Thurnher M., Mature dendritic cells induce T-helper type-1-dominant immune responses in patients with metastatic renal cell carcinoma, Urol. Int. 63 (2000) 151-159.

[39] Riollet C., Rainard P., Poutrel B., Kinetics of cells and cytokines during immune-mediated inflammation in the mammary gland of cows systemically immunized with Staphylococcus aureus $\alpha$-toxin, Inflamm. Res. 49 (2000) 486 496.

[40] Salmon H., Mammary gland immunology and neonate protection in pigs, in: Mol J.A., Clegg R.A. (Eds.), Biology of the mammary gland, Kluwer Academic / Plenum Publishers, New York, 2000, pp. 279-286.

[41] Sanchez-Carlo V., Wilson R.A., McDonald J.S., Packer R.A., Biochemical and serologic properties of Escherichia coli isolated from cows with acute mastitis, Am. J. Vet. Res. 45 (1984) 1771-1774.

[42] Satoshi H., Suzuki-Miki K., Takeyoshi I., Maki I., Takashi K., Nobuhisa N., Yamamoto-Noriko T., Meijin T., Effects of paternal lymphocyte 
immunization on peripheral Th1/Th2 balance and TCR Vbeta and Vgamma repertoire usage of patients with recurrent spontaneous abortions, Am. J. Reprod. Immunol. 43 (2000) 107-115.

[43] Schuhbauer D.M., Mitchison N.A., Mueller B., Interaction within clusters of dendritic cells and helper T cells during initial Th1/Th2 commitment, Eur. J. Immunol. 30 (2000) 1255-1262.

[44] Shafer-Weaver K.A., Corl C.M., Sordillo L.M., Shifts in bovine CD4+ subpopulations increase T-helper-2 compared with T-helper-1 effector cells during the postpartum period, J. Dairy Sci. 82 (1999) 1696-1706.

[45] Smith J.L., Hogan J.S., Smith K.L., Efficacy of intramammary immunization with an Escherichia coli J5 bacterin, J. Dairy Sci. 82 (1999) 2582-2588.

[46] Soltys J., Quinn M., Selective recruitment of T-cell subsets to the udder during Staphylococcal and Streptococcal mastitis: analysis of lymphocyte subsets and adhesion molecule expression, Infect. Immun. 67 (1999) 6293-6302.

[47] Sordillo L.M., Peel J.E., Effect of interferon-) on the production of tumor necrosis factor during acute Escherichia coli mastitis, J. Dairy Sci. 75 (1992) 2119-2125.

[48] Taylor B.C., Dellinger J.D., Cullor J.S., Stott J.L., Bovine milk lymphocytes display the phenotype of memory $\mathrm{T}$ cells and are predominantly CD8+, Cell. Immunol. 156 (1994) 245-253.

[49] Tomita G.M., Nickerson S.C., Owens W.E., Wren B., Influence of route of vaccine administration against experimental intramammary infection caused by Escherichia coli, J. Dairy Sci. 81 (1998) 2159-2164.

[50] Tomita G.M., Ray C.H., Nickerson S.C., Owens W.E., Gallo G.F., A comparison of two commercially available Escherichia coli J5 vaccines against $E$. coli intramammary challenge, J. Dairy Sci. 83 (2000) 2276-2281.

[51] Tyler J.W., Cullor J.S., Osburn B.I., Bushnell R.B., Fenwick B.W., Relationship between serologic recognition of Escherichia coli O111: B4 (J5) and clinical coliform mastitis in cattle, Am. J. Vet. Res. 49 (1988) 1950-1954.
[52] Tyler J.W., Cullor J.S., Thurmond M.C., Douglas V.L., Dellinger J.D., Humoral response in neonatal calves following immunization with Escherichia coli (strain J5): the effects of adjuvant, age and colostral passive interference, Vet. Immunol. Immunopathol. 23 (1989) 333-344.

[53] Tyler J.W., Cullor J.S., Spier S.J., Smith B.P., Immunity targeting common core antigens of Gram-negative bacteria, J. Vet. Int. Med. 4 (1990) 17-25.

[54] Vandeputte-Van Messom G., Burvenich C., Roets E., Massart-Leën A.-M., Heyneman R., Kremer W.D.J., Brand A., Classification of newly calved cows into moderate and severe responders to experimentally induced Escherichia coli mastitis, J. Dairy Res. 60 (1993) 19-29.

[55] Van Werven T., Noordhuizen-Stassen E.N., Daemen A.J.J.M., Schukken Y.H., Brand A., Burvenich C., Preinfection in vitro chemotaxis, phagocytosis, oxidative burst, and expression of CD11/CD18 receptors and their predictive capacity on the outcome of mastitis induced in dairy cows with Escherichia coli, J. Dairy Sci. 80 (1997) 67-74

[56] Wagter L.C., Mallard B.A., Dekkers J.C.M., Leslie K.E., Wilkie B.N., Characterization of immune responsiveness and disease occurrence during the peripartum period. J. Dairy Sci. 79 Suppl. 1 (1996) 119 (abstr.).

[57] Washington E.A., Katerelos M., Cahill R.N.P., Kimpton W.G., Differences in the tissue-specific homing of $\alpha \beta$ and $\gamma \delta$ T cells to gut and peripheral lymph nodes, Int. Immunol. 6 (1994) 1891-1897.

[58] Wegmann T.G., Lin H., Guilbert L., Mosmann T.R., Bidirectional cytokine interactions in the maternal-fetal relationship: is successful pregnancy a Th2 phenomenon? Immunol. Today 14 (1993) 353-356.

[59] Young Y.H., Sheep immunology and goat peculiarities. Leukocyte migration, in: Pastoret P.P., Griebel P., Bazin H., Govaerts A. (Eds.), Handbook of Vertebrate Immunology, Academic Press, London, 1998, pp. 493-496.

To access this journal online:

www.edpsciences.org 